\title{
İktidarın Gücünün Gözüktüğü Yer: İzleme ve Disiplin
}

\author{
Dilek Canyurta,
}

\section{Özet}

Modern dönemlerde teknolojik gelişmelerle doğru orantılı olarak, başkaları üzerinde iktidar sahibi olmayı isteyen her kesimin imkanları artmıştır. Bu çalışmada amaç, son günlerde Facebook ve Twitter gibi popüler sosyal medya mecralarında kişisel mahremiyetin ihlalleri noktasında ortaya çıkan skandalların verdiği ivme ile iktidarın gücü, izlenme, disiplin gibi konular hakkında farkındalığın arttırılmasıdır. Bu yapılırken Foucault'un perspektifi tercih edilmiştir. Foucault'un tarif ettiği iktidar biçimi, sadece devlet erkini ifade etmemekte, başkalarına hükmeden her kişi ve kurum bu tarif içerisine girmektedir. Bu çalışmada izlenme konusuna odaklanılırken, 'Ponepticon modeli' hapishaneler üzerinden, iktidar-suç-izlenme arasındaki ilişkilere vurgu yapılmıştır. Sonuç olarak anlaşılmıştır ki tıpkı eski çağların iktidar sahipleri gibi günümüzde de iktidar olmak isteyenler toplum hakkında olabildiğince bilgi sahibi olmak için gözetleme/izleme ile ilgili her yöntemi kullanmaktadırlar. İzleme ve izlenmenin son derece yaygın hale gelmesi onun normalleşmesini de beraberinde getirmiş adeta bir alışkanlık boyutuna varmıştır.
Anahtar Kelimeler

Foucault

İzleme

İktidar

Disiplin

Makale Hakkında

Geliş Tarihi: 02.10.2019

Kabul Tarihi: 10.06.2020

Doi: 10.18026/cbayarsos.628557

\section{Where the Power of Power Occurs: Monitoring and Discipline}

\begin{abstract}
In modern times, in parallel with the increase in technological opportunities, the possibilities of every segment that wants to have power over others have increased. The aim of this study is to raise awareness about the power of power, monitoring and discipline with the acceleration of the scandals that have emerged in recent days in social media such as Facebook and Twitter in the context of violations of personal privacy. In doing so, Foucault's perspective was preferred. The form of power described by Foucault does not only express the power of the state, but every person and institution that rules others is included in this description. This study focuses on the issue of relationship between power-crime-monitoring through, especially Ponepticon model prisons. As a result, , As a result, who want to be in power today use every method of monitoring in order to have as much information about society as possible. The fact that monitoring became extremely widespread has brought its normalization to a habitual dimension.
\end{abstract}

Keywords

Foucault

Monitoring

Power

Discipline

About Article

Received: 02.10.2019

Accepted: 10.06 .2020

Doi: $10.18026 /$ cbayarsos.628557

a dcanyurt@gmail.com

b Öğr. Gör. Dr., Bolu Abant İzzet Baysal Üniversitesi/ Bolu ORCID: 0000-0001-8509-6141 


\section{Giriş}

Tarihten bu güne, iktidarı elinde bulunduran siyasal erkin ve ekonomik güç yapılarının toplumsal yapı üzerinde; sosyal kurumların oluşmasından, insan davranışlarına hatta mimariye kadar olan etkileri pek çok düşünürün dikkatini çekmiştir. İktidarın iktidar olabilmesini sağlayan unsurlar sorgulana gelmiştir. Bu süreci sorgulayan düşünürlerden en dikkat çekenlerden bir tanesi ise Michel Foucaultdur. O'nun anlatımlarında, özellikle Avrupa'da ilkel çağlardaki acımasız ve doğrudan insan bedenine yönelik cezalandırma yöntemleri vardır. Bunlar iktidarın birey üzerindeki yansımaları olarak karşımıza çıkar. Daha sonraki dönemde bu tür cezalandırmalar doğurduğu çeşitli komplikasyonlar nedeniyle, iktidarın gücüne güç katma etkisini yitirdiğinde, siyasal maliyetlerinin artması temel bağlamında terk edilmişlerdir. Bu terk ediş; bedene verilen acı çektirmenin, ruha yönelik olarak dönüştürülmesinden başka bir şey değildir. Bu terk ediş; iktidarın toplum üzerindeki yetkinliğinden vazgeçtiğine ve onları özgür bırakmaya niyetli olduğuna delil de değildir. Toplumsal düzen kapitalist döneme girerken, insanları cezalandırma yöntemleri de yerini, insanları adeta 'iyi birer çalışan elemana dönüştürme makinesi' olan hapishane tekniğine bırakmıştır. Bu yazımızda Foucault'un bir sembol olarak kullandığı ve çok önem verdiği; Bentham'ın hayalini kurduğu 'panopticon' tipi cezaevi modeli bağlamında, suçun cezalandırılması süreçlerinin nasıl evirildiği ve bu sürecin toplumsal değişim ve dönüşüme etkileri incelenecektir.

$\mathrm{Bu}$ model insanı disipline eden, kuşatan ve gözetleyen, böylece insanı dönüştüren bir modeldir. Hangi tür olursa olsun iktidarın(sadece hükümet anlamında değil) beklentileri; kendi gücünü arttırma adına, ceza, disiplin, güvenlik, izleme gibi unsurlardan alabildiğine yararlandığı yeni bir toplumsal düzeni oluşturmasıdır. Özellikle ‘Panopticon' türü cezaevi mimarisi, iktidarın gücünün devamı için toplumları 'izleme' bağlamında günümüzde de dikkate değer bir modeldir. Bütün iktidarların toplumu, hatta bireyleri izleyerek, tanıyarak onlara karşı tam yetkin olma, onları kuşatma istekleri, gelişen teknoloji ve insanların güvenlik fobileriyle birleşince sınır tanımaz bir hal almış durumdadır. Diğer yandan bütün iktidarlar için en önemli konu meşruiyet konusudur. Kendi gelecekleri adına yönettikleri toplumlarda meşruluklarını sağlama ihtiyacı hissetmişlerdir. Meşruiyetlerini sağlayarak, kendilerini daha bir güçlü bulmuşlardır.

Bilinen bir gerçek varsa, rasyonel bir toplum oluşturma hedefindeki modern iktidarlar, bu hedefe yönelik olarak akılcı ve bilimsel ilkelere dayanan söylemler üretmişlerdir. Bu sayede de kendilerini meşrulaştırma yolları bulmuşlardır. Adorno, Horkheimer, Habermas, Popper, Foucault, Feyerabend ve Lyotard gibi düşünürler ise modern iktidar sürecine eleştiriler yönelten düşünürlerin başında gelmektedirler (Karakehya, 2008: 93). Bu nedenle yazımızda tartıştı̆̆ımız; iktidar, ceza, disiplin, izleme gibi bütün bu unsurlar, alışageldiğimiz sıradan bakış açısından aykırı bir bakış açısı sunan ve böylece iktidar-ceza-disiplin-izleme gibi konularda sıra dışı farkındalıklar üreten Foucault'nun perspektifinden yapılacaktır. Özellikle son dönemlerde Twitter ve Facebook gibi sosyal medya ağlarının kurucuları tarafından yapılan özür açıklamaları ile kullanıcılarının kişisel bilgilerinin üçüncü şahısların eline geçtiği anlaşılmış olduğundan, böylesi güncel bir konunun sadece güvenlik boşluğunun ötesinde anlamlar taşıyor olduğunun anlaşılması amaçlanmıştır. Böylece yeni gelişmeler ışı ğında konunun tekrar ele alınarak farkındalık oluşturulması hedeflenmiştir. Her ne kadar literatürde benzer çalışmalar yapılmış olsa da insanların izlenme ve gözetlenmesinin devam ediyor olması böylesi bir çalışmanın yapılmasını da önemli kılmaktadır. 


\section{Avrupa'da Orta Çağda Suç-Ceza-İktidar}

Foucault'un (2006) anlatımlarıyla, Orta Çağ Avrupa'sında insanlar acımasızca ve adaletsizce cezalandırılıyorlardı ve cezalandırma sistematiğinin temeldeki en derin nedeni, iktidarın kendi gücünü halkına kabul ettirmesi idi. Ortaçağ Avrupa'sında paranın kullanım olarak gelişmediği bu dönemde, bedensel cezaların öne çıktığı görülmüştür. Bu dönemde insan bedenlerinin üretim gücü olması bunun temel nedenini oluşturur. Siyasal ve ekonomik yapının cezaların şekli üzerinde ne denli etkili olduğu, iktidarın beden üzerine doğrudan müdahaleleri olarak karşımıza çıkmaktadır. Foucault'un (2006) o dönemin Fransa'sı üzerinden yaptığı örneklemeler, kan dondurucu nitelikte acımasız ve ölüme giden yolda bile acı çektirmenin türlü tekniklerini tarif etmektedir.

Ceza vermenin çok ötesine geçen bu vahşet ve acı çektirme geleneklerinin temelinde Foucault'un (2006) deyimiyle 'koskoca bir iktidar ekonomisi' vardır. Bu cezalandırma sistemini incelediğimizde, sınırsız yetkili olarak hükümdar karşımıza çıkarken, yargılama sistemi tamamen haksızlıklarla doludur. Arzu edilen ifadelerin alınması amacıyla, kırbaçlama ve her türlü gayri insani yöntem kullanılmıştır (Dolu, 2011: 87). Sorgulama süreci son derece gizli yürütülürken, cezalandırma süreci bu gizliliğin tam tersine halkın önünde gerçekleştirilerek adeta hükümdarın gücünün sergilendiği bir arena haline getirlmiştir (Foucault, 2006: 48). Aslında bütün bu süreçler siyasal bir zemine oturmaktadır ve iktidarın gücünün simgeleridir. Buradan amaç, bütün halkı hükümdarın bedenler üzerindeki sınır tanımayan hâkimiyeti karşısında hassas hale getirmektir ve bu hâkimiyet silahlı bir hâkimiyettir. Azap çektirme ritüelleri uzun yıllar sürmüştür ve bunun ardında yatan temel neden ise iktidarın gücünü sergilendiği bir alan olmasıdır (Foucault, 2006: 59-68). Foucault'a (2000) göre şiddet, iktidarın ilkel biçim ve değişmeyen sırrıdır. İktidar başkalarının eylemi üzerinde eylem yapabilen güç olarak ifade edilirse, iktidar üzerinde eylem yaptığı bireylerden ya rıza bekleyecektir ya da şiddet yoluyla zorla bu rızayı elde edecektir. Bu nedenle iktidar için hem rıza hem şiddet gereklidir.

\section{İhtişamlı Ceza Törenlerin Sonu}

18. yüzyıldan sonra değişen ekonomik yapı ile toplumlar ve düşünce dünyası da değişikliğe uğramış ve buna bağlı olarak cezalandırmadaki eski yöntemler terk edilmiştir. Bütün bunlar ekonomik sistemin dayatmasıyla bağlantılı olarak yeni iktidar araçlarını doğurmaktadır. Artık halk önünde gerçekleştirilen ihtişamlı ve acımasız iktidar gösterileri şeklindeki ayinsel idam cezaları, devrin reformistleri tarafından gaddarca ve insanlık dışı olarak nitelendirilmiştir (Boyne, 2009:159). Bu dönemin adaletsiz düzenine, batıl inançlara ve cehalete karşı tepki olarak İngiltere'de Thomes Hobbes, John Locke ve Jeremy Bentham, Fransa'da Charles Montesquieu, Voltaire, Jean-Jacques Rousseau ve Claude Adrien Helvetius, İskoçya' da David Hume, Adam Smith, Almanya' da İmmenual Kant, İtalya' da Cesare Beccaria gibi düşünürler reformist bir grup olarak ortaya çıkmışlardır (Dolu, 2011: 88). Bu azap çektirme yöntemleri halkı tehdit eden siyasal bir tehlike olarak görülmeye başlanmıştır (Boyne, 2009:159).

$\mathrm{Bu}$ sorgulama sürecinin başlangıç nedenlerini incelediğimizde, Foucault'a (2006) göre, o dönemde idamların en dikkat çeken bir özelliği; infazların halkın toplandığı büyük alanlarda yapılması ve halkın da bu infaz sürecine katılmasıdır. Böylece halk idam edilen kişi ile birebir diyaloğa girebilmekte ve bazen zaten öleceğini bilen mahkûm iktidar aleyhinde özgürce konuşabilmekte idi. Bu durum halkın iktidara karşı negatif düşünceler kazanmasına da neden olabilmekte idi. Ayrıca hafif suçlara verilen ağır cezalar karşısında halk isyanları da çıkmıştır. 
Bütün bunlarla, artık bu tür yöntemlerin hükümdarın iktidarını perçinleme işlevinin kalmadığı anlaşılmıştır. Bir de üzerine suçluların efsaneleşmeleri eklenince iktidarların gücü açısından durumun ciddiyeti kendini göstermiştir. Cezalandırma yöntemlerinin nihai hedefi hükümdarın ne kadar güçlü ve muktedir olduğunun halka kabul ettirilmesi ve halkın boyun eğdirilmesi olduğu için ortaya çıkan ve halk ayaklanmasına varan, siyasi iktidarı zedeleyen bu durumları terk etmek mecburiyeti doğmuştur. Böylece cezalarda insanileşme ve bedene yönelik cezalarda azalma gerçekleşmiştir.

İktidarı siyaseten zayıflatan nedenlerin dışında; toplumsal, ekonomik ve siyasal hayattaki değişimlerin bu sorgulama sürecine etkisi de yadsınamaz bir gerçektir. Çünkü 17. yüzyıldan başlayarak Avrupa'da, toplumsal yaşam ve örgütlenme biçimini ifade eden ekonomik alanda sanayileşme, üretim tarzı ve ilişkilerinde geleneksel yöntemlerin tamamen değişmesi ve düşünsel alanda eski dogmatik düşüncelerin bırakılarak akılcılığın ön plana çıkması şeklinde bir modernleşme süreci başlamıştır. Bütün bunlara rağmen Avrupa'da cezanın seyirlik olmaktan çıartılması, diğer ifadeyle doğrudan fiziksel şiddet uygulanmasının son bulması, ancak 1830-1848 yılları arasında gerçekleşebilmiştir (Karakehya, 2008: 89-97).

\section{Yeni Tarz: Gözetleme ve Dönüştürme}

Bedene yönelik acı çektiren cezalandırma sistemlerinin bırakılması ile yerine ikame edilen hapsedilme süreçleri, Bentham'ın fikir babalığını yaptığı hapishane modeli ile iktidarın ortaçağ ütopyasının adeta şekillenmiş haliydi. Bugün izlenmenin sembolü olarak kullanılan 'Ponepticon' modeli ile şekillendirilmiş cezaevi, gerçekte tamamen kuşatılmış, disipline edilmiş ve dönüştürülmüş bir toplum sisteminin yansımalarıdır. Artık eskiden uygulanan ceza ritüellerinin yerini, devlet aygıtının kendisiyle bütünleşmiş kapalı ve hiyerarşik büyük bir mimari yapı ile cezalandırma, yani insanları kapatma şeklinde cezalandırmaya geçilmiştir. Aslında bu tarz cezalandırma da iktidarın bedenleri kuşatmasının başka bir görünümünden ibarettir. Suçluların bu şekilde cezalandırılması, insanlık uygarlığı kadar eski olmakla birlikte, hapsetmenin standart bir biçim kazanması ancak 17. yüzyıldan sonra mümkün olabilmiştir (Kızmaz, 2007:17). Aslına bakılırsa çağdaş hapishanelerin kökenlerini, daha eski zamanlardaki hapishanelerle ya da zindanlarla değil de, 'işliklerle' ilişkilendirmek daha doğru olacaktır. İşlikler, 17. yüzyıldan itibaren pek çok Avrupa ülkesinde kurulmuştur. Feodalizmin çözüldüğü bu dönemde, iş bulamayan köylüler, serseri haline gelmişti. İşliklerde bu kişilere yemek veriliyordu ve bu insanlar, buralarda aşırı derecede çalışmaya zorlanmaktaydılar (Giddens, 2000: 197). Bu dönem, henüz ortaya çıkan kapitalizmin, yeni iş sahaları için siyasal güçleri zorlamaya başladığı bir dönemdir. Foucault'a göre cezalandırma sürecindeki bu dönüşümün temel nedeni kapitalizmin gelişmesi ve burjuvazinin kuruluş sürecinin gerçekleşmiş olmasıdır. Böylece mahkûmlar hem cezalarını çekecekler hem de çalışarak üreteceklerdir. Bu anlamda 17. yüzyılda İngiltere'de 'Workhouse' adıyla anılan kapatma mekânları açıldı. 1622'de Hambourg'da kurulan benzer mekânlarda tüm kapatılanların çalışma mecburiyetleri vardı ve böylece emek piyasasında fiyatlar düşecek ve üretim maliyetleri azalacaktır (Timur, 2005: 54-68).

Burada konuyu netleştirme adına kısaca cezalandırma şekillerinin dönüşümü hakkında bir sıralama yapılacak olunursa: Birinci evrede; cezalandırmanın ıstırap veren bir gösteri (seyirlik) olmaktan çıkması ve ıslahın amaçlanması, ikinci evrede; suçlu iradenin cezalandırılmaya başlanması ve son olarak da cezanın infazında gözetimin boyutlarının artması şeklinde sıralanabilir (Karakehya, 2008: 97). Diğer yandan bir tersten okumayla, yaygınlaşan ve gelişen cezaevleri kurma sürecinin arka planında ekonomik nedenler yatmakta olduğu ifade 
edilebilir. Çünkü buralardan "çok sayıda yeni işçi yetiştirmek, mahkûmları serserilikten çıkartarak işçi piyasasına hazır hale getirmek, işçi piyasasında rekabet ortamı hazırlamak, serserilerce malı tahrip olanlara vergi iadesinden kurtulmak" gibi ekonomik nedenlerdi bunlar. Buradan amaç mahkûmları çalışmaya yönlendirmektir. Bu nedenle ceza süreleri buna göre ayarlanmıştır. Aşırı kısa hapisler bunu sağlamayacağı gibi uzun olanlar da sağlamayacaktır.

Foucault'a (2006) göre "yönetsel bir aygıt olan hapishane, aynı zamanda zihinleri dönüştürecek bir makine olacaktır". Bu süreçte cezanın uygulandığı alan kişinin zamanıdır, bedenidir, gündelik hareketleridir ve aynı zamanda ruhudur. Bu suçlunun hapishanedeki bütün zamanlarını nasıl kullanacağı önceden belirlenerek ve bu şekilde alışkanlık kazandırılmaya çalışılarak yapılmak isteniyordu. Daha da ileri gidilerek itaatkâr bedenler imal edilmesi tasarlanıyordu. Hapishanelerin ortaya çıkma süreci Merkantilizm veya Kalvincilik felsefi bakış açısıyla da bağdaştırılabilir. Çünkü işgücü ve çalışma bu felsefenin temel görüşüdür. Avrupa'da ilk önce yoksullar, dilenciler, işsiz güçsüzler, serseriler çalıştırılabilir hale gelmeleri için hapishanelere doldurulmuş ve kapalı alanlarda çalışmayı kabul eder hale getirilmişlerdir (Ergüden, 2007: 42).

Hapishanelerin kuruluşu ve gelişimi nasıl olursa olsun, nihayetinde iktidarın bir güç gösteri mekânıdır ve amacı da bireyi dönüştürmektir. Fakat bununla yetinmez iktidarı elinde tutanlar. Nihai hedef; sonsuz dönüşümler zincirini kurmaktır (Saygıll, 2007: 193). Foucault (2006) iktidar olan güçlerin, halkın hayatının ve bedenlerinin en küçük unsularını dahi denetim altına alma istekleri bulunduğunu ifade etmektedir. Ona göre, bu istek sadece hapishanelerde gerçekleşmemekte, aynı zamanda okul, kışla, hastane, işyerleri sayesinde halk disipline edilmek istenmektedir. Bu disiplini sağlamanın yolu olarak, her ayrıntının iyi bir şekilde gözlemlenmesi gerekmektedir (Foucault, 2006: 173-176). Egemenlik ve sermaye ikilisi başarıya ulaşırsa, otoritenin en aşkın haline ve egemen olabilme eylemi de toplumu yöneten politik bir makineye dönüşecektir (Hardt ve Negri, 2012: 105). Zaten bu nedenle de çoğunluğu yönetebilme adına, çoğunluğa belli bir düzen dayatılmaktadır (Foucault, 2006: 183-184).

18 yüzyıldan beri gelişen bu disiplin anlayışı; insanların okullarda, hapishanelerde veya işyerlerinde daha itaatkâr hale getirilmeleri değildir. İnsanlar üretim etkinlikleri, iletişim şebekeleri ve iktidar ilişkileri ağında giderek daha denetimli ve ekonomik hale getirilmeye çalışılmaktadır (Foucault, 2006: 72). Foucault'a (2006) göre "gözetim, aynı anda hem üretim aygıtının bir iç parçası hem de disiplinsel iktidarın uzmanlaşmış bir çarkı olduğu ölçüde, belirleyici bir ekonomik işlemci haline gelmektedir". İktidarlar açısından 'gözetleme'nin cezalandırmadan daha etkili olduğunun anlaşılmasıyla, cezalandırma politikalarında köklü değişiklikler yapıldı ve vücudu cezalandırmak yerine, ruhu ıslah etmek tercih edilir oldu. Diğer taraftan tıpkı gözetim gibi bir kavram daha ortaya çıkmaktadır ki bunun adı normalleştirmedir. Yani bireyleri çeşitli yöntemler kullanarak (cezalandırma ve ödüllendirme) belli bir standarda uydurma eylemi. Okul, kışla, hastane, işyeri, hapishane bunların işleyiş sistemleri bütünsel sistemin işleyişi esasına göredir ve aksatanlar 1slah edilir. Sistem bütün hayatınızı kurgular (Ergüden, 2007: 63) ve bu normalleştirmenin ta kendisidir.

Normalleşme tıpkı gözetim gibi, iktidarın gücünü toplum üzerinde sergilediği bir alan olarak, karşımıza çıkmaktadır. Dolayısıyla da artık iktidar kendini görünmez bir alana çekilmiştir fakat kurduğu disiplin ortamlarıyla boyun eğdirdiği her bireyin zihninde zorunlu olarak görünür olmuştur (Foucault, 2006: 231-235). Aslında bu anlatılanlar bir siyasal düşün izdüşümleridir (Ergüden, 2007: 43); insanlar üzerinde iktidar olabilmenin, onların ilişkilerini 
denetleyebilmenin ve mükemmel yönetilen disiplinli toplum düşüdür. Foucoult'a (2006) göre, 19. yüzyıldan beri bu amaca yönelik olarak hastaneler, okullar, hapishane gibi kurumlar toplumu disipline etme adına iktidar tarafından kullanıla gelmektedirler.

Bentham'ın ortaya attığı ve 'Panopticon' adıyla anılan cezaevi modeli mimari olarak; çevrede halka tipi bir bina, merkezde halkanın iç çeperine bakan büyük pencereleri olan bir kule, çevredeki bina ise bölümlere ayrılmış ve her bir bölüme bir mahkûm düşecek şekilde ayarlanmıştır. Bu mahkûmlar sürekli görülebilecek bir konumdadır. Bu mimarinin en büyük etkisi, mahkûmlardaki sürekli izlenme psikolojisi oluşturmasıdır. Mahkûm görülebilmekte, ancak merkezi kuleden kendisini izleyeni asla görememektedir. Bunun sayesinde iktidar otomatikleşmekte adeta makineleşmektedir. Bu ilişkiden hayali bir mekanizma doğmakta ve mahkûmu iyi davranmaya, akıl hastasını sakin olmaya, işçiyi çalışmaya, okul çocuğunu özenli olmaya iten ve insanları standartlaştıran bir sistem oluşmaktadır (Foucault, 2006: 251-254). Bu mimari sistemde hapishanenin tecrit ve gözetleme fonksiyonu öne çıkmaktadır. Bir taraftan her bir mahkûm hücrelere koyulurken hücrenin, kapatmak, 1şıtan yoksun birakmak ve saklamak işlevleri ters yüz edilmektedir. Artık tam ışık altında olma ve bir gözetmenin bakışı ile kuşatılmaktadır (Bozkurt, 2000: 136). En can alıcı yanı ise bu modelin bütün topluma uygulanabilecek bir model olmasıdır (Ergüden, 2007: 43) ve zaten önemini de buradan almaktadır.

Panopticon tarzı iktidarın; üretimi arttırma, ekonomiyi geliştirme, eğitimi yaygınlaştırma, kamusal ahlakı yükseltme işlevleri vardır (Foucault, 2006: 261). Disiplinler artık giderek yararlı birey imal eden teknikler şekline dönüşmektedir (Foucault, 2006: 265). Çünkü iktidar, hayatı bütün yönleriyle kuşatmayı ve kendi istediği şekilde yönlendirmeyi temel işlevi olarak görür (Hardt ve Negri, 2012: 45) ama disiplini sadece bir kurumlar zinciri olarak görmek yanlıştır. O bir iktidar tipidir koskoca bir usuller topluluğudur. Panopticon tipi disiplin kapalı usulleri genelleştirmekte ve toplumun tamamına yaymaktadır (Foucault, 2006: 271). Aslında son noktada disiplinci iktidar, bütün toplumu sermaye ve devletin komutasında ve kapitalist üretim sisteminin bir aracı olmaya yönlendirir ve toplumu adeta bir 'fabrika-toplum' haline evirir (Hardt ve Negri, 2012: 251). Bu sistem her iktidarın istediği şeyi, yani insanları disipline etme yoluyla yönetim erginin daha az masraflı kılınmasını hedeflemektedir ve aynı zamanda artan üretime disiplinli toplumlar hazırlama işlevi de söz konusudur (Foucault, 2006: 174). Her yerde önemli olan disiplindir bunu hapishaneler kadar fabrikalarda ve bir fabrika işçisinin evinin mimarisinde bile bulabiliriz (Hacking, 2002: 66). Foucault'un ifadeleriyle "iktidar ekonomisini yöneten eski el koyma-şiddet ilkesinin yerine, disiplinler yumuşaklık-üretim-kar ilkesi ikame etmişlerdir" (Foucault, 2006: 275). Çeşitli eğitim ve öğretim süreçleri de aynı zamanda iktidarın güçlü kılınması içindir ve bunu sağlaması beklenir (Falzon, 2001: 18). Çünkü modern toplumda çeşitli kurumlar adeta bireyleri üreten fabrikalar konumundadır; yaşam boyu okul, kışlaya veya fabrikaya gidilir ve her bir kurum bireyi şekillendiren bir araçtır (Hardt ve Negri, 2012: 205).

Belki de iktidarın muktedir olabilmek adına yaptığı değişmeyen tek şey bunu yapabilme adına, değişimin ta kendisi olacaktır. Yine de Foucault gibi düşünürlerin tarihin içinde yaptıkları tersine okumalar sayesinde gizli perdeler aralanacaktır (Saygılı, 2004: 94). Batının ekonomisinin temeli olan sermaye birikimi aynı zamanda eski iktidar biçimlerine de son vererek kendi ekonomik çıkarlarına uygun yeni iktidar biçimlerini de getirmiştir (Foucault, 2006: 277-285). Ponapticon tipi izlenebilen ve iktidar tarafından adeta sinir uçlarına kadar 
erişilen bir toplumda bilinçlere, bedenlere ve toplumsal ilişkilere müdahale etmek onları kontrol etmek son derece kolaydır (Hardt ve Negri, 2012: 46).

19. yüzyıla gelene kadarki süreçte, suçu cezalandırmak için hapsetme, nadir uygulanan bir yöntemdir (Giddens, 2000: 197). Hapishanelerin kullanılmaya başlanması ile diğer cezalandırma çeşitleri terk edilmiştir. Bu gün de olduğu gibi o günlerde de hapishanelerden beklenen amaç bireylerin sslah edilmesidir (Timur, 2005: 74). Bu süreç, cezanın törensel bir seyir unsuru olmaktan çıkması, bireylerin insanca muamele görmesi bakımından önemli bir gelişmedir ve aynı zamanda kendi içerisinde tutarlı bir uygulamadır. Ancak ıslahın, bu uygulamalarla ne kadar gerçekleştirilebileceği ise son derece çelişkilidir (Karakehya, 2008: 98). Dahası hapishanelerin gerçekten çözüm ürettiği konusu şüphelidir ki zaten pek çok tutuklu hapishaneden çıktıktan sonra hapishanelere geri dönmektedir (Foucault, 2006: 336). Dahası 20. yüzyılın ikinci yarısından bu yana uluslararası denetim raporlarında sürekli olarak bu kurumların insanlık dışı uygulamalarından bahsedilmekte ve Batı son 300 yıldır bu konuyla alakalı reform tartışmalarını bitirememiş durumdadır (Ergüden, 2007: 37). Tüm başarısız yönlerine rağmen hapishaneler hala etkin bir yöntem olarak kullanılmaktadır (Foucault, 2006: 336-352). Hapishane ortamlarında pekişen yasa dışlık iktidarın gücünün devamlılığını pekiştirmiş, 19. yüzyıldan bu yana yumuşamış gözüken cezalandırma sistematiği, mantık olarak değişmemiş ve yine iktidarın gücünü gözüktüğü bir alan olarak devam etmektedir (Foucault, 2006: 360-387).

\section{Yüzyılda İktidar-Gözetlenme}

Modern dünya artık apaçık iktidarın şiddet kullanarak insanların yönetilmesi fikrine sıcak bakmamakta ve bu yöntemler daha çok tepkisel karşılık bulmaktadır. Zaten toplumu bütün birimleriyle kuşatmak ve üzerinde eylem yapabilmek yetisi olarak iktidar gücü, günümüz dünyasında gelişen teknoloji sayesinde bunu şiddet kullanmadan yapılabilmektedir. Önceki bölümlerde de üzerinde durulduğu üzere aslında iktidarı pekiştirmenin en güzel belki de en ekonomik ve tepkisel karşılığının olmadığı yöntem; toplumu bütün kılcallarına kadar izleme, herkesin hakkında bilgi sahibi olabilme kudretidir. Bunu yapabilen bir iktidarın toplumu dönüştürmesi de bir o kadar kolay olacaktır.

Foucault'a (2000) göre, bir toplumda iktidar ilişkilerini analiz edebilmemiz için belli noktalara bakmamız gerekecektir: 1- Başkalarının üzerinde eylem yapabilmenizi sağlayan bir farklılığınız olması: ekonomik, üretim sürecindeki konum, uzmanlık ve kültürel farklılıklar gibi. Bu durum modern dünya veya geçmiş toplumlarda çarpıcı bir şekilde görülmektedir (Eskiden aristokratlar ve burjuvazi modern dünyada büyük sermaye sahipleri veya kendilerini gelişmiş, diğerlerini az gelişmiş diye sınıflandıranlar.). 2- İktidar etmekten beklenen amaç: Ayrıcalıkların korunması, kar birikimi, bir memuriyet veya mesleğin uygulama alanı ve statüye dayalı bir otorite kurmak. İktidar demek sadece hükümet demek değildir. Dolayısıyla bir memurun amiri karşısında kendini kuşatılmış hissetmesi, bir fabrika sahibinin karşısında işçinin durumu da bir tür iktidar ilişkisidir. Her iki durumda da iktidarı elinde tutanın diğer taraf üzerinde eylem yetisi vardır. 3- İktidarlar bu becerilerini; sözün gücüyle, silah gücüyle, ekonomik avantajlarıla ve kayıt sistemi olsun olmasın izleme sistemleriyle ve toplumun önceden belirlenmiş normlarıla gerçekleştirirler (Foucault, 2000: 71). Bu unsurları ortaçağda kralların bir sözleriyle insanları idamdan alabildiği anda ne kadar muktedir olabildiklerini gösterdikleri, silahlı adamlarıla insanları idam etmelerinde ve ekonomik güce sahip senyörlerin suç işleseler bile ceza almamalarında görürüz. Günümüz modern toplumlarındaki iktidar sahipleri için; sözün ve silahın gücü hala devam etmekle 
birlikte izlemenin gücü daha bir artmaktadır. Çünkü izleme şiddet içermez ve siyaseten en az riski taşır. Aynı zamanda çok etkili bir tekniktir.

Sancar'a (2004) göre, Modern dönem siyasal teorisinde uygar devlet, şiddetten arınma, ondan kurtulma veya şiddeti yaşamın önemli alanlarından tasfiye etme konusundan sorumlu bir proje olarak anlaşılmaktadır. Bu anlayış devlet aygıtını, başka bir ifade ile iktidar konumundaki gücü, adeta egemenliğinin sınırlarını aşarak, küreselleşme sayesinde şiddet temelli ama 'çağdaş' görünümlü hale dönüştürmüştür. Küreselleşmeyle birlikte devlet kurumu, teknolojiyi kullanarak, toplumun en mahrem köşelerine nüfuz edecek kadar bir genişleme imkânını bulmuş ve dünya, adeta parmaklıkları olmayan şeffaf bir hapishaneye dönüşmüştür (Atay, 2009). Bunun temel etkeni belki de insanların güvenlik ihtiyacindan kaynaklanmaktadır. Güvenliğe önem veren yenidünya düzeni, beraberinde insanları aptallaştıracak derecede sinırlı bir düzen sunan toplumsal sistemi de konfigüre etmiştir (Falzon, 2001: 76). Yeni iktidar paradigması normların inşası, sistem ve hiyerarşidir de denilebilir ve değerler dizisi iktidarın kendini meşru kılmasının geniş kapsamlı üretimidir. 19 yüzyılda hayali kurulan disiplin toplumu, günümüzde kendisine sunulan hayat tarzıyla bir kontrol toplumu haline gelmiştir (Hardt ve Negri, 2012: 35-44).

Bireylerin iletişim ya da eylemlerinin sistematik olarak araştırılması ya da izlenmesi olarak açıklanabilecek olan 'gözetim' kavramı Foucault tarafından çok etkili bir şekilde vurgulanmıştır ve son dönemde, internet gibi bilgi iletişim teknolojilerinin gelişimine paralel olarak özel bir önem kazanmıştır (Bozkurt, 2000: 71). İşte bu gelişen teknolojilerle birlikte yaşamın her alanı gözetlemeye dayalı cihazlarla donatılmıştır. Belki de bunun en çarpıcı örneğini MOBESE kameraları oluşturur. Diğer yandan görmeye dayalı gözetim tek başına yeterli görülmediğinden, modern iktidar yapıları, kendi gücünün devamı adına bireyler hakkında bilgi depolayarak onları izlemektedirler (Tümurtürkan, 2010: 4).

Bu izleme işlevi sadece devlet kurumları ile kısıtlı kalmamaktadır. Nasıl ki Foucault iktidarı tanımlarken bir başkasını etkileme ve yönetme edimini arzulayan her birey ve kurumu bu tanıma dahil etmise, güncel olarak, bu izleme ve bilgi depolama faaliyeti geniş kapsamlı şekilde gerçekleşmektedir. İktidarlar, mümkün olduğunca ayrıntılı bilgi depolayarak ve bireylerin davranışlarını izleyerek otorite ve gücünü arttırmaktadır (Sucu, 2011: 127). Bu durumun, iktidar olmak isteyen siyasetçiden, malını pazarlamaya çalışan şirketlere, eşinden kuşkulanan kişilere kadar geniş bir yelpazesi vardır. Bu konunun en çarpıcı örneği, 2016 Amerika Birleşik Devletlerindeki (ABD) seçimlerinde meydana gelen bir skandalla kendini göstermektedir. Bu olayda İngiliz analiz şirketi Cambridge Analytica 2018 yılında, 50 milyon Facebook kullanıcısına ait verileri Trump lehine kullandıklarını açıklamıştır (cnntürk.com, 2018). İktidar olmak isteyen bir siyasetçi açısından gerçekleşen bu olayın akabinde, yine en yaygın olarak kullanılan sosyal medya ağı olan Twitter'dan 2019 yılında gelen özür ile kullanıcılar, kendi verilerinin reklam şirketlerine verildiğini öğrenmiş oldular (ntv.com.tr, 2019). İktidar artık hapishaneler, silahlar, cezalar gibi fiziksel kuvvetiyle değil aynı zamanda; MOBESE'ler, görüntü ve iletişim kayıtları, teknik izlemeler, internet denetimleri, parmak izi ve fotoğraf arşivleri, DNA bankası ve çipli kimlikler ile bireylerin hayatını tamamen kuşatmıştır ve böylece disipline edilen insan, bilinçaltı ile de böylece şekillenmektedir (Atay, 2009: 2).

Devlet tarafından yapılan gözetleme ve izleme işlevlerinin, tepki görmemesinin temel nedeni ise insanların kendilerini güvende hissetme ihtiyacından kaynaklanmaktadır. Bütün bunlar güvenlik için gerekmektedir. Telefonlar suçluların önlenmesi için dinlenebilir hale gelmiştir, 
parmak izleri suçlular için alınır, MOBESE kameraları da trafik suçları için lazımdır. Suçlularla mücadele aynı zamanda sıradan bireylerin de izlenmesi sonucunu doğurmuştur. Dolayısıyla Foucault'un iktidar ile suçlular arasında kurduğu ilinti doğrulanmış gözükmektedir. Bu güvenlik söylemleri bireyin güvenliğinden çok devletin güvenliğini öne çıkarmakta 'devlet güvenliği' gerekçesiyle 'kişi güvenliği' sınırlandırılabilmekte ve kişisel haklar çiğnenebilmektedir.

Birleşmiş Milletler İnsan Hakları Bildirgesi'ne göre gizlilik temel bir insan hakkı olarak tarif edilmiştir. Gerek ulusal gerekse uluslararası antlaşmalarla ayrıca pek çok yasa uyarınca, özel yaşamın gizliliğinin korunmasına yönelik çok sayıda düzenleme getirilmiştir. Zaten özel yaşamının mahremiyetine saygı göstermek zorunda olunduğu konusu herkes tarafından kabul edilmektedir (Bozkurt, 2000: 71). Açık bir gerçeklik olan 'kişisel hayatın mahremiyeti' konusu nasıl olmuştur da böylesi hafife alınır hale gelmiştir. Bu sorunun cevabı, iktidar sahiplerinin güvenlik ile ilgili, toplumu ikna eden makul sebeplerinin varlığında gizlidir. Konunu en çarpıcı örnekleri, 11 Eylül olaylarından sonra ABD'de ve Avrupa'da alınan güvenlik önlemleri ile görülmektedir. 2001 yılında çıkarılan USA Patriot Act (ABD Vatanseverlik Yasası) ile hukuki emir olmadan da telefon ve iletişim araçları dinlenebilecektir ve daha önce polise ve istihbarat servislerine bilgi toplamada koyulmuş olan hukuki engellerin tamamı ortadan kaldırılmıştır (Paye, 2009: 59-60). Görüldüğü üzere ABD halkının zihinlerini altüst eden ve toplumsal bir travmaya yol açan bu terör olayı, güvenlik korkusunda olan halkı özgürlüğünden vazgeçmeye adeta razı etmiştir. Yasa dışılıklarla iktidar burada adeta el ele dolaşmaktadır. Bu konudaki örneklere başka Batı ülkelerini de eklemek mümkündür: Almanya'da üst aramaları, kimlik kontrolleri ve ihtiyati tutukluluk gibi konularda istisnalar oluşturulmuşken, İtalya'da mahkeme mevzuatı ile ilgili istisnalar çıkarılmıştır. Burada terörle mücadele kapsamında tutuklanan bir kişinin avukatını seçme hakkı dahi bulunmamaktadır. Büyük Britanya, 'Terörün Önlenmesi Yasası' ile polislere şüphelendikleri kişileri tutuklama yetkisi vermiştir. Dahası bu yasalar terörle mücadele kapsamında çıkmalarına rağmen olası tehlikeler bertaraf olsa bile devamlılıklarını sürdürmektedirler (Paye, 2009: 98-100).

Gözetim teknolojileri toplumun refah, huzur, güvenlik ve düzen gibi beklentilerine cevap olarak kullanılmakta, bu yapılırken de kişileri yaşamın her alanında denetim altına almakta ve mevcut egemen güçlerin iktidar olma yetilerini en üst seviyeye çıarmaktadır. Artık özel hayatın mahremiyeti diye bir şey kalmamaktadır (Tümurtürkan, 2010: 17). Bu izleme, yönlendirme ve denetleme faaliyeti sadece devlet bazında işlememektedir. Bütün iktidar sahipleri; yukarıda değinildiği üzere, bireyler üzerine iktidar etme edimine sahip olabilen herkes, bunu kullanmaktadır. İsteyen herkes kendi küçük görünmez hapishanesini kurabilmektedir. İşveren, işçilerinin yanına kamera koymaktadır, okullar koridorlara kamera koymakta, oturduğu eve gelenleri kontrol etmek isteyen ev sahibi, apartman kapısına kamera koymaktadır, bebeğinin iyi bakılmadığına inanan anne, evine gizli kamera koymaktadır. Bunların yüzlerce örnekleri verilebilir elbette. Buradan anlaşıldığı üzere gözetleme, iktidarı pekiştiren bu altın ve adeta sihirli teknolojik unsur, büyük küçük tüm iktidar sahiplerinin kullanimindadir.

Bir diğer değinilmesi gereken konu, izlenmenin artık kanıksanır olmasıdır. İtiraf.com ve BBG.com gibi popüler internet sitelerinin kişisel mahremiyeti hiçe saymaları, adeta bireyleri de birbirini gözetler hale getirmiş ve bu durum gözetimin artık 'popüler bir kültür olarak' algılanması veya kabul görmesi sonuçlarını doğurmuştur (Dolgun, 2004: 66). Bilgi ve iletişim çağında bireyden kurumlara kadar herkeste diğeri hakkında bilgi sahibi olma merakı 
yerleşmiş durumdadır. Resmi otoriteler daha sağlıklı kamu hizmetleri sunmak, suçlularla mücadele etmek, vergi toplamak gibi, kabul edilebilir nedenlerle düzenli olarak enformasyon toplamakta, enformasyonun güç olduğunun bilincindeki büyük işletmeler de sıradan insanlar hakkında sürekli olarak veri biriktirmeye devam etmektedir. Hiç kimse kendisi hakkında nerelerde, ne gibi verilerin toplandığını bilmemektedir (Bozkurt, 2000: 72). Sıradan bireylere ait her tür bilgi gittikçe 'şeffaflaşırken' bu bilgileri toplayanlar alabildiğine 'gizli' kalmaktadır (Dolgun, 2004: 62).

$\mathrm{Bu}$ ifade edilen gözetleme şekillerinin Bentham'ın panopticon modelinin özellikleriyle ne kadar uyuştuğu da ortadadır. Sizi gözetleyen birileri vardır ama siz onları asla bilemez ve göremezsiniz. Foucault'un bireyleri dönüştürme mekanizmalarını açıklarken ifade ettiği normalleştirme ile bireyleri istenen kalıba sokma süreci de tam burada işlemektedir. Modern dünyanın bireyleri için bilişim süreçleri o kadar doğal ve sıradan bir hayatın parçasıdır ki Facebook, İnstagram, Twitter kullanımı adeta ruhsal, bedensel bir ihtiyaç gibi görülmektedir. Dolayısıyla yaşadığı iletişim mekanizmalarını normal gören bir bireyin, bu konuyla alakalı farklı bir bakış sergilemesi ve ters okumalar yapması zor görünmektedir. Yine de bütün bu deliller ve incelemelere rağmen modernizmin toplumu bir genel hapishaneye sıkıştırdığını söylemi ise çok iddialı bir söylem olsa gerektir (Timur, 2005: 78).

Foucault'un iktidar ilişkilerini analiz süreçlerini incelemeye devam edersek 4- İktidar kendi kurumlarını kurarak kendi iktidar yetkinliği arttıracak ve toplumu bu şekilde kuşatacaktır (Foucault, 2000: 78). Devlet kurumları bir tarafa, şirket yapılarından, iletişim sistemlerine, dilsel ilişkilerden, kişisel ilişkilere kadar bu disiplin ağını hazırlayacaktır (Hardt ve Negri, 2011: 158). Son olarak da iktidar ancak gücünü rasyonel bir zeminde sergileyebilecektir (Foucault, 2000: 78). Tarihten bu güne iktidarlara baktığımızda ne kadar şiddet yöntemlerine başvurulsa bile halkın ikna edilerek, onaylanarak bu işlevin üretilmesi son derece ekonomik ve kolaydır. Diğer şekliyle sonuçları iktidarın tamamen yitirilmesi şeklinde gerçekleşebileceğindendir ki modern iktidarlar 'Ponepticon' tipi farkına vardırmadan normalleştirerek dönüştürmekte ve toplumları istedikleri şekilde yönlendirebilmektedirler.

\section{Tartışma ve Sonuç}

Gücü elinde bulunduran, kendisini ekonomik siyasal veya toplumsal nedenlerle farklı gören ve bu nedenle bireyleri ve toplumları istedikleri şekilde kendi hedefleri doğrultusunda yönlendirmek, belli standartlara uydurmak ve dönüştürmek isteyen iktidar odakları eskiden de vardı, modern dünyada da vardır, gelecekte de olacaktır. Fakat bu iktidar unsurları gelişen ve değişen ekonomik toplumsal teknolojik yapılara bağlı olarak bu iktidar etkinliklerini halka yöneltmede farklı teknikler kullanmışlardır. Bu teknikler gelişen teknoloji ve bakış açıları ile birlikte sürekli dönüşüm sürecindedirler denilebilir. Faoucault'un (2006) anlatımlarından öğrendiğimize göre, ortaçağ Avrupa'sında gücünü halka kabul ettirmek ve adeta hâkimiyetini ilan etmek amaçlı korkunç ceza törenleri, zamanla yerini çok iyi tanımlanmış yasalara ve hapishane sistemiyle suçluların cezalandırılmasına bırakmıştır. Fakat bu noktada ceza bedene değil ruha çektirilir olmuş ve bu sistemin en önemli metaforunu da Bentham'ın 'Ponepticon' tipi cezaevi oluşturmaktadır. Bu model modern kapitalizmin hayalini kuruduğu; kuşatılmış, bir kalıba dökülmüş, standart insanı oluşturmanın hayalidir. İktidar bunu yaparken makul sebeplerini de ortaya koyarak yapmaktadır. Dolayısıyla bu tür faaliyetlerinin nedenini, insanların en hassas noktası olan güvenlik ihtiyacı ile açıklamıştır. 
20. yüzyıl modern çağına bilişim teknolojileri damgasını vurmuştur ve yüzyıllar geçse de 'Ponepticon metaforu' önemini yitirmemiştir. Artık modern iktidarlar, işyerlerindekileri, yollardakileri, okul koridorlarındakileri kameralarla gözetlemektedir. İnsanların bilgisayarları ve cep telefonları ile belkide evlerinin en kuytu köşesinde yazdıkları paylaşımları birileri tarafından depolanmakta veya izlenmektedir. Sokaklar, apartmanlar izlenmekte, internette girilen her site kayıt edilmektedir. İzleme ve gözetleme, başkalarını kuşatma edimi sadece devlet tarafından yapılmamakta, işyerinde işveren, apartmanda yönetici, malını pazarlama derdindeki şirketler, iktidar olmak isteyen siyasiler bunu yapmaya devam etmektedirler.

İktidar, Poneptikon, izlenme, kişisel mahremiyet gibi konularda yazılmış pek çok çalışma bulmak mümkündür. Ancak dünyanın adeta bir izleme ve izlenme çılgınlığına girdiği şu dönemde, konunun güncel hali ile tekrar gündeme getirilmesi önem kazanmaktadır. Zira Facebook ve Twitter'ın kullanıcılarından özür dilemiş olması, büyük bir skandal olarak tarihe geçmiş olsa bile, insanların bu mecraları kullanmaya devam ediyor olmaları, araştırılması gereken ayır bir konu olarak sıcaklığını korumaktadır. Dahası bu durum insanlık tarafından adeta kanıksanmıştır ve insanlar sosyal ağlarda kendi özellerini paylaşmaktan hiç çekinmemektedirler. Bu denli kuşatılmışlık altındaki insanlığın bunu normalleştirmesi ise belki de izlemenin diyalektiği olarak ortaya çıkmaktadır. Diğer yandan kendilerini adeta demokrasinin beşiği olarak tarif eden ABD'deki 2016 başkanlık seçimlerine, hali hazırda başkanlık yapan Trump lehine Facebook'daki kullanıcıların siyasi görüşlerinin sızdırılmış olması da çok sıcak bir gelişme olarak karşımızda durmaktadır. Böylesi bir gelişme demokrasinin zedelenmesi neticesini doğuracağından dolayı önemli sakıncalar içermektedir. Modern dünyada ortaya çıan bu gelişmeler yine Foucault'un erken dönem Avrupa'sındaki tarihi olaylardan modern dünyaya gelişen süreçten çıkarımlar yaparak ortaya koyduğu görüşlerini doğrular niteliktedir.

\section{Kaynakça}

Atay, H. (2009). Temel haklar ve ilkeler doğrultusunda iletişimin denetlenmesi tedbiri ve kişisel güvenlik “biri bizi dinliyor”. Ceza Hukuku Dergisi, 4(10), 157-175.

Boyne, R. (2009). Foucault ve Derrida Aklın Öteki Yüzü, (çev.) İsmail Yılmaz. Ankara: Bilgesu Yayıncilik.

Bozkurt, V. (2000). Gözetim toplumu ve internet: Özel yaşamın sonu mu?. Birikim Dergisi, 136, 69-74.

Cnntürk.com, (2018, Mart 21). 50 Milyon Kişinin Facebook Verileri Trump İçin Kullanılmış. Eylül 10, 2019 tarihinde, https://www.cnnturk.com/dunya/dw/50-milyon-kisinin-facebookverileri-trump-icin-kullanismis adresinden alınd1.

Dolgun, U. (2004). Gözetim toplumunun yükselişi: Enformasyon toplumundan gözetim toplumuna, Yönetim Bilimleri Dergisi, 1, 55-74.

Dolu, O. (2011). Suç Teorileri: Teori, Araştırma ve Uygulamada Kriminoloji. Ankara: Seçkin Yayincilik.

Ergüden, I. (2007). Hapishane Çă̆ı Kapatılan İnsan. İstanbul: Versus Kitap.

Falzon, C. (2001). Foucault ve Sosyal Diyalog Parçalanmanın Ötesi, (çev.) Hüsamettin Arslan. İstanbul: Paradigma Yayınları. 
Foucault, M. (2006). Hapishanenin Doğuşu, (çev.) Mehmet Ali Kılıçbay. Ankara: İmge Kitabevi Yayınları.

Foucault, M. (2000). Özne ve İktidar, (çev. ) Işık Ergüden ve Osman Akınhay. İstanbul: Ayrıntı Yayınlar1.

Giddens, A. (2000). Sosyoloji , (çev.) Cemal Güzel. Ankara: Ayraç Yayınları.

Hacking, Ian (2002). Foucault'nun arkeololojisi. V. Urhan (Ed.), Foucault ve Bilginin Arkeolojisi içinde, İstanbul: Paradigma Yayınları.

Hardt, M., \& Negri, A. (2011), Çokluk, (çev.) Barış Yıldırım. İstanbul: Ayrıntı Yayınları.

Hardt, M., \& Negri, A. (2012), İmparatorluk, (çev.) Abdullah Yılmaz. İstanbul: Ayrıntı Yayınları.

Karakehya, H. (2008). Modern cezalandırma sistemlerinin büyük anlatıları. İ̈̈HFM C. LXVI, 90, 87-108.

Kızmaz, Z. (2007). Cezaevi ve hapsetmenin suçu engellemedeki etkisi. Dumlupınar Üniversitesi Sosyal Bilimler Dergisi, 17, 1-25.

Ntv.com.tr., (2019, Mayıs 14). Konum Verilerini Paylaşan Twitter Özür Diledi, Temmuz, 12, 2019 tarihinde, https://www.ntv.com.tr/teknoloji/konum-verilerini-paylasan-twitter-ozurdiledi,cR_hK9tcoEe2pkScdc8YAQ adresinden alındı.

Paye, J. C. (2009). Hukuk Devletinin Sonu: Olağanüsüt Halden Diktatörlüğe Terörle Mücadele, (çev.) G. Demet Lüküslü. Ankara: İmge Kitabevi.

Sancar, M. (2004). Şiddet, şiddet tekeli ve demokratik hukuk devleti. Doğu Batı Dergisi, 3, 2545.

Saygılı, A. (2004). Mikro iktidarın bir fiziği: hapishane. Ankara Üniversitesi Hukuk Fakültesi Dergisi, 2(63), 177-196.

Sucu, İ. (2011). Gözetim toplumunun karşı ütopya yüzü: İktidar güçleri ve ötekiler. Atatürk İletişim Dergisi, 2, 125-140.

Timur, T. (2005). Felsefe İzlenimleri: Sartre, Althusser, Foucault, Derrida. Ankara: İmge Kitabevi.

Tümurtürkan, M. (2010). Gündelik hayatın gözetimi "Panoptikon Toplumu”. ETHOS: Felsefe ve Toplumsal Bilimlerde Diyaloglar Dergisi, 3, 4-19. 